\author{
Review Article
}

\title{
REVIEW OF JWARAHARA GUTIKA YOGAS CONTAINING VATSANABHA IN SAHASRAYOGAM
}

\section{KV Reshma Phalgunan1*, Madavi Subhashchandra²}

${ }_{1}^{*}$ PG Scholar, ${ }^{2}$ HOD, Associate professor, Department of Rasasastra evum Bhaishajyakalpana, R.A. Podar Medical College (Ayu), Worli, Mumbai India.

Article info

Article History:

Received: $27-10-2021$

Revised: 08-11-2021

Accepted: 20-11-2021

KEYWORDS:

Vatsanabha, Jwara, Sahasrayogam,

Antidote of

Vatsanabha, Fever.

\begin{abstract}
Vatsanabha is Vishavarga dravya mentioned in many of the Ayurveda Samhitas, which is commonly used in Ayurvedic medicinal preparations. It has a property of Jwarahara, Amaghna, Swedajana which is very useful in Jwara cases. The drugs like Parada, Gandhaka, Hingula along with Vatsanabha shows fast action on Jwara. In Ayurveda there are many formulations mentioned with Jwarahara properties. In this article we are studying about 17 Jwarahara Gutika yogas containing Vatsanabha which are mentioned in Sahasrayogam. Purpose of this study is to analyse these Yoga in the aspect of their ingredients, Bhavana dravya, Anupana, Sevana vidhi, and their role in management of Jwara. When we analysing each and every ingredients on these Yogas there are certain similarities in ingredients, Bhavana dravya, Anupana of these medicines. Most of these ingredients have Deepana Pachana karma, Katu Thikta rasa, Ushna veerya, Katu vipaka etc which are beneficial for Samprapti vighatana of Jwara. As Sahasrayogam is a compilation of popular formulations which are commonly used by ancient physicians of Kerala, it is assumed that all of this Yoga were once in practice. These formulations are to be kept in tablet form which is very convenient for their administration, palatability etc. But very few of them are available in market. In this current scenario of Covid pandemic Ayurveda field should rethink about these potent medicines of Jwara for the well being of our community, and further study and clinical trial also needed to know their action on Jwara.
\end{abstract}

\section{INTRODUCTION}

Sahasrayogam is a compilation of Ayurvedic formulations which are mostly used by ancient Vaidya (physicians) of Kerala. It contains Kashaya (decoction), Gulika (tablet), Vataka (tablet), Choorna (powder), Bhasma (ashes), Kshara (alkali), Lehya, Arishta (fermented decoction), Asava (fermented herbal juice), Taila (medicated oil), Ghrita (medicated ghee) formulations for different diseases. Most of them are collected from manuscripts and compiled together in a book named Sahasrayogam. Besides polymorphous formulations, single drug recipes are also indicated for the treatment of different diseases in this book.

\section{Access this article online}

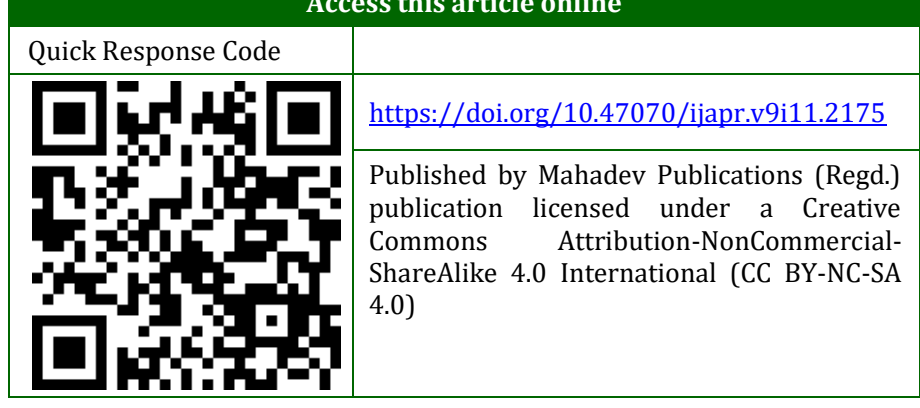

Gutika yogas (tablet formulations) of Sahasrayogam contain many Jwarahara yogas (antipyretic formulations). Most of them contain Vatsanabha as an ingredient.

In Ayurvedic classics, Jwara is considered the Rogadhipati i.e., king of all diseases. It is mentioned as a disease as well as a symptom of other diseases too. The term Jwara means the condition in which the mind, sense organs, and the body all are affected (Dehendriya mana santapakara).

Mithya ahara, Vihar (unwholesome food and physical activities) leads to an aggravation of Vatadi doshas which afflicts Amashaya (stomach) and gets mixed up with Agni (digestive fire), it follows the course of Rasa (the essence of food) and obstructs the channels of Rasa and Sweda (sweat channels), suppress the activity of Pachakagni (digestive fire) and expels the heat from the site of digestion spreading it all over the body thus causing Jwara (fever).[1] 


\section{Vatsanabha}

Vatsanabha (Aconitum ferox) is a drug that comes under Maha visha varga of Ayurveda. Though it is a poisonous drug its therapeutically efficiency is very much useful in Ayurveda formulations. Aconitum ferox is also known as Aconitum virorum is species of 'monk's hood', in the family of 'Ranunculaceae'. It contains a large amount of alkaloid pseudaconitine, which is a deadly poison.[2]

For therapeutic purpose, Vatsanabha can be used only after Shodhana (purification). Shodhana of Vatsanabha is to be done in Gomutra (cow's urine) Swedana (fomentation) in Dolayantra for 3 Yama. [3] Studies have shown that pseudoaconitine and aconitine were converted into far less toxic substances veratroyl pseudoaconine and benzoylaconine respectively in traditional Ayurveda Shodhana procedure. ${ }^{[4]}$

The Shuddha Vatsanabha is used judiciously for the internal administration of inappropriate dosage after thorough consideration of all the relevant factors that influence the dosage, the medicine acts like 'Amrita' (nectar). If this medicine is administered in higher doses, it stops cardiac activities and leads to death. ${ }^{[5]}$ Karma (therapeutic action) of Vatsanabha includes Sheetaprashamanam (alleviate coldness), Swedasanjananam (produce sweat), Deepana (digestive stimulant), Agnimandya Prashmanam (alleviate indigestion), etc indicates its excellent property of Jwarahara. ${ }^{[6]}$ Due to these properties, most of the Jwarahara formulations in Rasashastra contain Vatsanabha as an ingredient. Thribhuvana Keerthi Rasa, Anandha Bhairava rasa, Prathapalankeshwara Rasa, etc are some of the examples.

All these Agnimandya, Ama (undigested food) problems which is the main reason for Jwara can easily be managed by Vatsanabha due to its action on Srotas. A study of the chemical components of Vatsanabha shows that it has analgesic, anti-inflammatory, and immunomodulatory actions. ${ }^{[7]}$

\section{Vatsanabha containing Jwarahara Gutika Yoga from Sahasrayogam ${ }^{[8]}$}

Table 1: Yoga and Their Composition

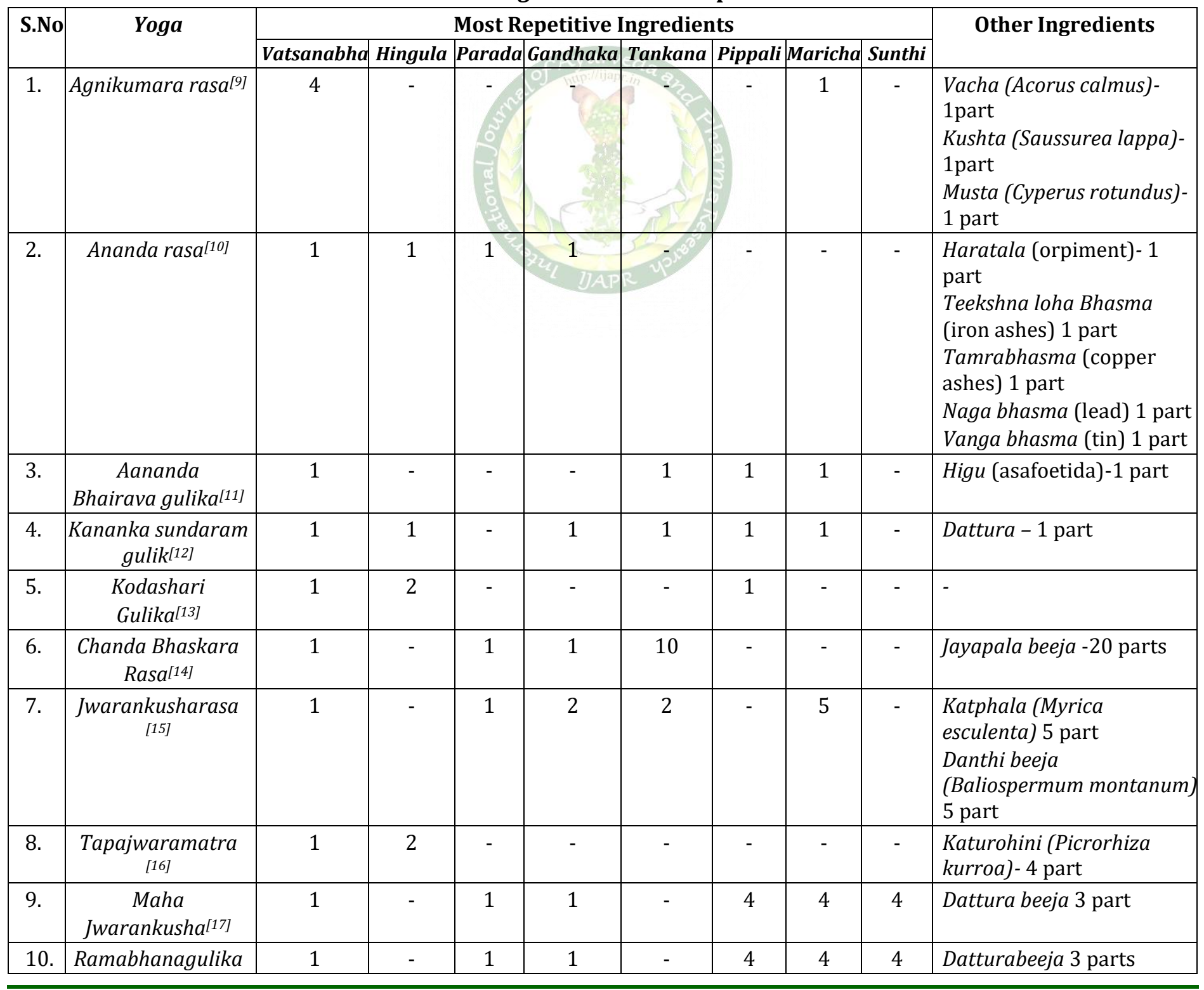


KV Reshma Phalgunan, Madavi Subhashchandra. Review of Jwarahara Gutika Yogas Containing Vatsanabha in Sahasrayogam

\begin{tabular}{|c|c|c|c|c|c|c|c|c|c|c|}
\hline & [18] & & & & & & & & & \\
\hline 11. & $\begin{array}{l}\text { Ramachandeshwara } \\
\text { rasa[19] }\end{array}$ & 1 & - & 1 & 1 & - & - & - & - & $\begin{array}{l}\text { Tamra- } 1 \text { part } \\
\text { Laksha (Laccifer lacca) } 1 \\
\text { part }\end{array}$ \\
\hline 12. & $\begin{array}{l}\text { Rogatrayari } \\
\text { Rasa[20] }\end{array}$ & 1 & - & 1 & 1 & - & 1 & 1 & 1 & Triphala ( 1 part \\
\hline 13. & $\begin{array}{c}\text { Vettumaran } \\
\text { Gulika[21] }\end{array}$ & 1 & 1 & - & - & 1 & - & 1 & - & $\begin{array}{l}\text { Ajamoda (Trachyspermum } \\
\text { ammi) } 1 \text { part }\end{array}$ \\
\hline 14. & $\begin{array}{l}\text { Sheeta matanga } \\
\text { Sinha }[22]\end{array}$ & 1 & - & 1 & - & 1 & - & - & - & $\begin{array}{l}\text { Shikhi tutha (copper } \\
\text { sulphate) } 1 \text { part } \\
\text { Manashila (realgar) } 1 \text { part } \\
\text { Haritala-1 part }\end{array}$ \\
\hline 15. & $\begin{array}{c}\text { Sarva Roga } \\
\text { kulanthakam }^{[23]}\end{array}$ & 1 & 2 & - & - & - & 1 & - & - & - \\
\hline 17. & Suryaprabha [25] & $1 / 16$ & - & 1 & 1 & - & 1 & 1 & 1 & $\begin{array}{l}\text { Hingu - } 1 \text { part } \\
\text { Triphala } 3 \text { part Jeraka } \\
\text { (Cuminum cyminum) } 1 \text { part }\end{array}$ \\
\hline
\end{tabular}

Out of these 17 Gulika Yogas, Agni kumara rasa, Ananda Bhairava rasa, Vettumaran gulika Suryaprabha are widely using in practice.

In Agnikumara rasa parts of Vatsanabha are 4 parts. But, Suryaprabha containing only 1/16 part Vatsanabha.

Tankana (borax) is an antidote for Vatsanabha, but many of the Yogas do not contain Tankana. In Sahasrayogam, Maricha Kashaya (decoction of black pepper) is mentioned as an antidote for Vatsanabha.[26,27] Other than Vatsanabha, Hingula (cinnebar), Parada (mercury), Gandhaka (sulpher), Tankana, Sunthi (dried ginger), Pippali (long pepper), and Maricha (black pepper) is the most repeating ingredients of this Yoga. (Table no.1)

Table 2: Indications

\begin{tabular}{|l|l|l|}
\hline S No. & Yoga & Indication as per Sahasrayogam \\
\hline 1. & Agnikumara Rasa & $\begin{array}{l}\text { Ama Jwara, Kapha Jwara, Peenasa (sinusitis), Pratishaya (rhinitis), } \\
\text { Agnimandya, Amatisara Pakwatisara, Swasa }\end{array}$ \\
\hline 2. & Aanada rasa & Sannipathaja Jwara Sheetha Jwara \\
\hline 3. & Anandabhairava Gulika & Sannipa Jwara, Sheeta Jwara \\
\hline 4. & Kanaka sundaram gulika & $\begin{array}{l}\text { Grahani (irritable bowel syndrome), Amashoola (pain), Arochaka, } \\
\text { Agnimandya, Jwara, Teevratisara }\end{array}$ \\
\hline 5. & Kodashari gulika & Sarvanga Sannipatha Jwara, Taruna Jwara, Sannipatha Jwara \\
\hline 6. & Chandabhaskara Rasa & $\begin{array}{l}\text { Pandu, Shopha, Mahodara (ascites), Udavarta, Gulma, Pleehodara } \\
\text { (Splenomegaly ), Arshas (piles), Krimi, Ajeerna, Amadosha, Purana } \\
\text { Jwara (later stage of fever), Prameha, Mootrakrichram (dysuria), } \\
\text { Ashmarivrana (ulcer due to calculi), Sarvavyadhiharam (alleviate all } \\
\text { disease), Agnideeptikara }\end{array}$ \\
\hline 7. & Jwarankusha Rasa & Tridosha Jwara \\
\hline 8. & Tapa Jwaramatra & Tapa Jwara \\
\hline 9. & Maha Jwarankusham & Jwara \\
\hline 10. & Ramabana gulika & Sarva Jwara \\
\hline 11. & Ramachandeshwara rasa & Sannipatha \\
\hline
\end{tabular}


Int. J. Ayur. Pharma Research, 2021;9(11):71-79

\begin{tabular}{|l|l|l|}
\hline 12. & Rogathrayari Rasa & Nava Jwara, Sannipatha, Tridosha Jwara \\
\hline 13. & Vettumaran gulika & $\begin{array}{l}\text { Jwara, Vayukshobha (irregularities of Vata), Chardi (vomiting), } \\
\text { Mootraghata (Gulma tumour), Sannipatha Jwara }\end{array}$ \\
\hline 14. & Sheetamatanga simham & Sheeta Jwara \\
\hline 15. & Sarva roga kulanthakam & $\begin{array}{l}\text { Rajayakshma, Vayukshobha, Swasa, Jwara, Agnimandya, Sannipatha } \\
\text { Vataroga }\end{array}$ \\
\hline 16. & Soochimukha rasam & $\begin{array}{l}\text { 13 Sannipatha Jwara, Visha, Unmada (mental disorder), Moha } \\
\text { (unconciousness ), Dhanurvata (tetanus) }\end{array}$ \\
\hline 17. & Suryaprabha & Shoola, Kasa, Swasa, Jwara \\
\hline
\end{tabular}

Most of these formulations are indicated mainly in different stages/types of Jwara. Ama Jwara/ Taruna Jwara/Nava Jwara (early stage of fever), Sannipathika Jwara (fever in which all 3 Doshas and Rakta are vitiated), Tridosha Jwara (all 3 Doshas vitiated fever) Tapajwara (fever in which temperature is more), Sheeta Jwara (fever in which temperature is less), Sarvanga Sannipatha Jwara (fever affecting whole body organs) etc terms are used by authors. (Table no 2) When we are going through the other indications Swasa (dyspnoea), Agnimandya, Arochaka (anorexia), Atisara (loose motion) etc diseases that are commonly accompanying Jwara can be seen. Out of these Yogas, Chandabhaskara Rasa, Vettumaran Gulika, Sarvarogakulanthakam, Soochimukharasa etc show a wide range of indications. Soochimukha Rasa is an exceptional Yoga as it is for external use in scalp after making an incision there. This Yoga can be used in all 13 types of Sannipathaja Jwara, Visha Unmada, Moha, Dhanurvata, etc. This indicates Suchimukharasa is used as an emergency medicine in ancient time's emergency cases. And for examine whether patient is alive or not. The doses of these formulations are told in $125 \mathrm{mg}$ to $1 \mathrm{~g}$.

Table 3: Properties of Main Ingredients

\begin{tabular}{|c|c|c|c|c|c|c|c|c|}
\hline \multirow[t]{2}{*}{ Properties } & \multicolumn{8}{|l|}{ Raw Drugs } \\
\hline & Vatsanabha $[28]$ & Hingula $[29]$ & Parada[29] & Gandhaka[30] & Tankana[31] $^{[3]}$ & Sunthi ${ }^{[32]}$ & Pippali [33] & Maricha[34] \\
\hline Rasa & $\begin{array}{l}\text { Katu (pungent) } \\
\text { Tikta (bitter), } \\
\text { Kashaya } \\
\text { (astringent) }\end{array}$ & Shadrasa & Shadrasa & Katu, Tikta & Katu & Katu & Katu & Katu \\
\hline Guna & Ushna (hot) & $\begin{array}{l}\text { Snigdha } \\
\text { (oily) }\end{array}$ & - & Snigdha & $\begin{array}{l}\text { Ruksha } \\
\text { (dryness) }\end{array}$ & \begin{tabular}{|l|} 
Tikshna \\
(sharpness) \\
Ruksha
\end{tabular} & Snigdha & $\begin{array}{l}\text { Laghu } \\
\text { lightness }\end{array}$ \\
\hline Veerya & Ushna & Ushna & - & Ushna & Ushna & Ushna & Anushna & Ushna \\
\hline Vipaka & $\begin{array}{l}\text { Madhura } \\
\text { (sweet) }\end{array}$ & Madhura & - & Katu & Katu & Madhura & Madhura & Katu \\
\hline Doshaghna & Tridoshahara & Kaphahara & Tridosha & Vata kapha & Kapha & $\begin{array}{l}\text { Kapha } \\
\text { Vatatmak }\end{array}$ & Vatahara & Sleshm \\
\hline \multirow[t]{9}{*}{$\begin{array}{l}\text { other } \\
\text { Karma }\end{array}$} & $\begin{array}{l}\text { Rasayana } \\
\text { (rejuvenating) }\end{array}$ & Jadaragni & Balya & Rasayana & Hridya & Dipana & Kaphahara & Chedana \\
\hline & $\begin{array}{l}\text { Swedala } \\
\text { (produce sweat) }\end{array}$ & Pachana & Vrishya & Deepana & Balya & Pachana & Deepana & Deepana \\
\hline & $\begin{array}{l}\text { Pithasantapaka } \\
\text { raka }\end{array}$ & Jwaraapaha & Rasayana & Pachana & Saaraka & $\begin{array}{l}\text { Amadoshah } \\
\text { ara }\end{array}$ & Ruchya & Ruchya \\
\hline & Rooksha & & Krimighna & Medhya & Deepana & $\begin{array}{l}\text { Vishama } \\
\text { Jwarahara }\end{array}$ & Rasayana & Jantu \\
\hline & Teekshna & & Ropana & & & & Hridya & Medohara \\
\hline & Laghu & & & & & & Vrishya & Chedi \\
\hline & Vikashi & & & & & & Rochana & Hridroga \\
\hline & Vyavayi & & & & & & & \\
\hline & Yogavahi & & & & & & & \\
\hline
\end{tabular}

Observing closely to all ingredients, suggest that it mostly contains Dipana, Pachana, and Agnivardhana dravyas. Collectively they mainly act on Rasavaha, Annvaha, and Swedavaha Srotas. 
Parad is Yogvaahi and Tridoshashamaka. Yogvaahitva, is an outstanding characteristic of mercury, these substances when combined with others besides maintaining their activity, increase the therapeutic activity of the other substance along with this. This is why the dose of the drug and time required for the onset of action is extensively reduced by mercurial compounds. [35]

Purified Sulphur is useful in cough, asthma, hepatomegaly, and splenomegaly, chronic fever, etc.[36] Parad and Gandhak together form a compound called Kajjali, this compound is found effective in diseases of all Strotas. The impact is Tridoshahara, which immediately spreads in the body when consumed clear the obstructed channels. ${ }^{[37]}$ Kajjali (black sulphide of mercury) can be used to treat a wide range of diseases when incorporated with the appropriate Anupana. Sarvamayahara, Vrishya, and Tridoshahara are the properties of Kajjali. Kajjali works synergistically and comprehensively with the herbal ingredients to provide a multi-targeted organ impact.[38]

Kajjali is not absorbed in the GI tract, it is postulated that it eventually acts as GI stimulant, locally also as a neuro-chemical irritant for the intestinal mucosa. ${ }^{[39]}$ It also acts as a catalyst and hence through its catalytic activity, better absorption of herbal pharmacological molecules is achieved. Hence, the net resultant activity of Kajjali is that it eventually increases the bioavailability of ingested drugs.[40]

Tankana is pungent in taste and hot in nature, it is good for the heart and act as an antidote for Vatsanabha as it compensates cardiac depressant action of Vatsanabha. It is Kaphnissaraka in nature and indicated in productive cough, asthma, chest congestion etc. It helps to improve menstrual flow. ${ }^{[41]}$ Vatsanabha as febrifuge agent is the best drug to reduce pyrexia by inducing sweat.

Trikatu (Maricha, Nagara, and Pippali) has Agni Deepana and Kapha- Vata Samana properties. Trikatu does Deepana, Pachana which is essential to reduce Ama and thereby Jwara. Sunthi is one of the best drugs for Amapachana. It is having antipyretic and antimicrobial properties. Maricha is of great value in fever especially as an adjuvant to more active febrifuge agents. It exerts a stimulant action throughout the entire course of the digestive system. Pippali acts as Rasayana i.e., rejuvenator. It has great action in intermittent fever and splenomegaly as having Jwaraghna and anti-malarial properties. ${ }^{[42]}$

Drugs like Gandhak and Pippali are Medhya in nature hence it also reduces Manasantap (mental impairment).[43]

Mineral ingredients present in the majority of the Yogas include Parada, Gandhaka, Hingula and Tankana.

\section{Importance of Bhavana Dravya}

Repeated Bhavana (levitation) of ingredients with appropriate Bhavana Dravya makes these formulations more effective and fast-acting.

The Yogas which contain Parada and Gandhaka method of preparation starts with, Sodhitha Parada and Gandhaka are properly triturated and Kajjali is prepared. Then assessment for colour, Varithrathwa, Rekhapoornathwa, as well as other Sidhalakshanas of the Kajjali is prepared. The remaining herbal and mineral ingredients, as well as the Kajjali and relevant Bhavana Davyas, specified in Yoga, are triturated later.

Table 4: Bhavana Dravya

\begin{tabular}{|l|l|l|}
\hline S No. & Yoga & Bhavana Dravya mentioned in Sahasrayogam \\
\hline 1. & Agnikumara Rasa & Ardraka swarasa \\
\hline 2. & Aanada rasa & $\begin{array}{l}\text { Triphala kashaya, Ardraka swarasa, Parpataka } \\
\text { kashaya, Sarpa pitta }\end{array}$ \\
\hline 3. & Anandabhairava Gulika & Jambheera swarasa \\
\hline 4. & Kanaka sundaram gulika & Bhanga kashaya \\
\hline 5. & Kodashari gulika & Jambheera swarasa \\
\hline 6. & Chandabhaskara Rasa & Nirgundi swarasa \\
\hline 7. & Jwarankusha Rasa & Water or Nirgundi moola kashaya \\
\hline 8. & Tapa Jwaramatra & Water \\
\hline 9. & Maha Jwarankusham & Jambheera swarasa, Ardraka swarasa \\
\hline 10. & Ramabana gulika & Sweta gunja leaf juice \\
\hline 11. & Ramachandeshwara rasa & Ardrka swrasa, Nirgundi patra swarasa \\
\hline 12. & Rogathrayari Rasa & Langali niryasa, Soorana, Chitraka, Ardraka, \\
\hline
\end{tabular}


Int. J. Ayur. Pharma Research, 2021;9(11):71-79

\begin{tabular}{|c|l|l|}
\hline & & Shigru, Punarnava niryasa \\
\hline 13. & Vettumaran gulika & Ardraka swarasa \\
\hline 14. & Sheetamatanga simham & Dhatura patra swarasa \\
\hline 15. & Sarva roga kulanthakam & Jambheera swarasam \\
\hline 16. & Soochimukha rasam & Sarpa pitta \\
\hline 17. & Suryaprabha & Jambheera swarasa \\
\hline
\end{tabular}

Ardraka Swarasa, Jambheera Swarasam, Nirgundi swarasam, Bhanga Kashaya, Dhatura Patra Swarasa, Sweta Gunja leaf juice, Langali Niryasa, Sarpapitta these are the Bhasvana Dravya for these formulations. All of these have Ushna Teekshna properties which will act on Ama when we go through its properties individually. Ardraka Swarasa having Katu Rasa (A.H-Tikta, Madhura ), Teekshna, Ruksha Guna, Ushnaveerya, and Madhura Vipaka, thus pacifies Vata, Kapha Dosha without aggravating Pitta. Effectiveness of Ardraka as an antioxidant, antiinflammatory agent, anti-nausea, and anti-cancer, infectious disease. ${ }^{[44]}$

Nirgundi is a non-steroidal anti-inflammatory drug. Chemical constituents present in Nirgundi act by blocking the synthesis of prostaglandins by inhibitory cyclooxygenase which converts arachidonic acid to prostaglandins inhibition of prostaglandin synthesis accounts for their analgesic, antipyretic and platelet inhibitory action. ${ }^{45]}$

Dhattura is quick in action indicated in Jwara, Shotha, Vedana. It is having potent analgesic and anti-viral properties. Datura metel is used traditionally for the treatment of various diseases including relaxation of smooth muscles, relief of fever, as well as gastrointestinal disorder. The study shows that the crude extract/fraction and the isolated compound, daturaolone exhibited significant gastrointestinal motility cessation, muscle relaxation, antipyretic effects.[46,47]

Bhanga possess Deepana, Pachana, Ruchya, Madakari, Vyavayi, Grahi (withholds secretions), Medhya (memory booster), Rasayana activities. The formulations levigated with Bhanga can be effectively applied in the management of clinical conditions like Jwara, Agnimandya, Ajeerna, Grahani due to its pharmacologic activities such as appetizer, digestive, antiemetic, antispasmodic, analgesic, anti-inflammatory, anticonvulsant, hypnotic, anti-psychotic and cataleptic, memory enhancer, anti-asthmatic, cardio-protective, anaesthetic, antiepileptic properties. ${ }^{[48]}$

The leaves of Gunja (Abrus precatorius) are used to treat cough, fever, and cold.[49,50] Sarpapitta (snake bile) is used in the preparation of 2 of these formulations, they are Anandarasa and Soochimukharasa.

\section{Importance of Anupana}

Anupana plays an important role in medicinal intake. With the help of same drugs, we can treat many types of diseases with different Anupana which means Anupana can easily intervene in the mode of action of the main drug. Specific Anupanas are recommended for different Jwaravasthas in some formulations. As we analyse these formulations Ardraka Swarasa, Nirgundi Swarasa is the main Anupana while patient having Ama Jwara or Nava Jwara. Ardraka and Nirgundi have Deepana and Amapachana properties as we mentioned earlier. (Table no 5)

Table 5: Anupana

\begin{tabular}{|l|l|l|}
\hline S No. & Yoga & Anupana mentioned in Sahasrayogam \\
\hline 1. & Agnikumara Rasa & $\begin{array}{l}\text { Honey and Sunthi choorna in Amajwara } \\
\text { Ardraka Swarasa and Nirgundi Swarasa in Kapha Jwara } \\
\text { Ardraka Swarasa in Peenasa, Pratishaya, } \\
\text { Lavanga kashaya or Lavanga choorna in Agnimandya, } \\
\text { Pippali kashya and Ardraka Swarasa in Sannipatha Jwararbha. }\end{array}$ \\
\hline 2. & Aanada rasa & Coconut water \\
\hline 3. & Anandabhairava Gulika & Jambheera swarasa \\
\hline 4. & Kanaka sundaram gulika & \\
\hline 5. & Kodasharigulika & \\
\hline 6. & Chandabhaskara Rasa & Guda \\
\hline 7. & Jwarankusha Rasa & \\
\hline 8. & Tapa Jwaramatra & Naaree ksheera, Sharkara \\
\hline
\end{tabular}




\begin{tabular}{|c|c|c|}
\hline 9. & Maha Jwarankusham & \\
\hline 10. & Ramabana gulika & \\
\hline 11. & Ramachandeshwara rasa & \\
\hline 12. & Rogathrayari Rasa & $\begin{array}{l}\text { Ardraka swarasa in Navajwara } \\
\text { Sannipatha Jwara in Kiratatikta Maricha kashaya }\end{array}$ \\
\hline 13. & Vettumaran gulika & $\begin{array}{l}\text { Ardraka swarasa in Jwara } \\
\text { Jeeraka kashaya in Vayukshobha } \\
\text { Chandra mulika swarasa in Chardi } \\
\text { (Pazhanthenga neeru) Coconut water in Mootraghata } \\
\text { Garlic juice in Gulma }\end{array}$ \\
\hline 14. & Sheetamatanga simham & Sugar \\
\hline 15. & Sarva roga kulanthakam & Sheets jala, Ardraka swarasa \\
\hline 16. & Soochimukha rasam & \\
\hline 17. & Suryaprabha & \\
\hline
\end{tabular}

When discussing Vettumaran gulika 'Pazhangenga Neeru' (coconut water) is told, because here Mootraghata is associated with Jwara, in that condition even if tender coconut is Vastishodhana cannot give because of its Amatwa. In Sarva Roga Kulanthakam cold water is told as an Anupana which is opposite to the Jwara.

\section{CONCLUSION}

Total 70 Gutika Yoga are explained in Sahasrayogam, 38 out of them are with Jwara as an indication. 17 out of them contain Vatsanabha as an ingredient. Vatsanabha is an excellent drug of choice for Jwara as it has Swedasanjanana, Deepana, Pachana actions. Most of these Yoga contains Hingula or Parada and Gandhaka as ingredients. A detailed examination of the Yogas mentioned in Jwara reveals that they are all excellent combinations of drugs with antipyretic, antibacterial, and antiviral properties. From these, we can understand ancient physicians has given much care to selecting drugs, during their preparation (Bhavana) and administration (Anupana) of each of these formulations for achieving maximum results. And the drugs like Sarpa Pitta, Bhanga are not much available for medicinal preparations due to Government restrictions. Studies on these drugs are also very few. Nowadays most of them are not available in the market, many of them are unfamiliar with standard practice. So potency of these formulations in the management of Jwara is not much known to society. Especially in this current Covid scenario, our healthcare system must adopt these medications for the wellbeing of the community.

\section{REFERENCES}

1. Akhila Retnam. A Keerthi V., Reenu Mathew Sudheera. A Critical Review of Herbo-Mineral Formulations in Jwara Chikitsa. International Journal of Health Sciences and Research. July 2021; 11(7); 394-406.

2. Dr.Ravinndra Angadi, Text book of Rasasastra, Varanasi; Choukambha surbharati Prakashan; 2020. p.542.
3. Dr.Ravindra Angadi, Text book of Rasasastra, Varanasi; Choukambha surbharati Prakashan; 2020. p.545.

4. S L Deore et al. J Young Pharm, Evaluation of toxicity of Vatsanabha (Aconitum ferox, Ranunculaceae) before and after Shodhana. Journal of Young Pharmacists. 2013; 5; 3-6.

5. Dr.Ravindra Angadi, Text book of Rasasastra, Varanasi; Choukambha surbharati Prakashan; 2020. p.543.

6. Ravindra Angadi, Sri Sadanada Sarma, Rasa Tarangini, (English translation), Varanasi; Caukamba surbharati prakashan, 2021; p.438.

7. Muhammad Shahzad Aslam, Muhammad Syarhabil Ahmad, Analgesic and Anti-inflammatory Activity of Genus Aconitum: A Phytochemical and Ethnopharmacological Review. Recent Advances in Biology and Medicine. 2016; 2; 94-112 https:// www.researchgate.net/publication/308793869.

8. K.V. Krishnan Vaidyan and S.Gopala Pillai. Sahasrayogam, Sujanapriya commentary, edition 32. Alappuzha; Vidyarambham publishers, October 2013, p.123-154.

9. K.V. Krishnan Vaidyan and S.Gopala Pillai. Sahasrayogam, Sujanapriya commentary, edition 32. Alappuzha; Vidyarambham publishers, October 2013, p123.

10. K.V. Krishnan Vaidyan and S. Gopala Pillai. Sahasrayogam, Sujanapriya commentary, edition 32. Alappuzha; Vidyarambham publishers, October 2013, p125. 
11. K.V. Krishnan Vaidyan and S.Gopala Pillai. Sahasrayogam, Sujanapriya commentary, edition 32. Alappuzha; Vidyarambham publishers, October 2013, p126.

12. K.V. Krishnan Vaidyan and S.Gopala Pillai. Sahasrayogam, Sujanapriya commentary, edition 32. Alappuzha; Vidyarambham publishers, October 2013.p127.

13. K.V. Krishnan Vaidyan and S.Gopala Pillai. Sahasrayogam, Sujanapriya commentary, edition 32. Alappuzha; Vidyarambham publishers, October 2013, p130.

14. K.V. Krishnan Vaidyan and S.Gopala Pillai. Sahasrayogam, Sujanapriya commentary, edition 32. Alappuzha; Vidyarambham publishers, October 2013. p131.

15. K.V. Krishnan Vaidyan and S.Gopala Pillai. Sahasrayogam, Sujanapriya commentary, edition 32. Alappuzha; Vidyarambham publishers, October 2013.p133.

16. K.V. Krishnan Vaidyan and S.Gopala Pillai. Sahasrayogam, Sujanapriya commentary, edition 32. Alappuzha; Vidyarambham publishers, October 2013.p133.

17. K.V. Krishnan Vaidyan and S.Gopala Pillai. Sahasrayogam, Sujanapriya commentary, edition 32. Alappuzha; Vidyarambham publishers, October 2013. p139.

18. K.V. Krishnan Vaidyan and S.Gopala Pillai. Sahasrayogam, Sujanapriya commentary, edition 32. Alappuzha; Vidyarambham publishers, October 2013. p143.

19. K.V. Krishnan Vaidyan and S.Gopala Pillai. Sahasrayogam, Sujanapriya commentary, edition 32. Alappuzha; Vidyarambham publishers, October 2013. p142.

20. K.V. Krishnan Vaidyan and S.Gopala Pillai. Sahasrayogam, Sujanapriya commentary, edition 32. Alappuzha; Vidyarambham publishers, October 2013. p144.

21. K.V. Krishnan Vaidyan and S.Gopala Pillai. Sahasrayogam, Sujanapriya commentary, edition 32. Alappuzha; Vidyarambham publishers, October 2013. $\mathrm{p} 147$

22. K.V. Krishnan Vaidyan and S.Gopala Pillai. Sahasrayogam, Sujanapriya commentary, edition 32. Alappuzha; Vidyarambham publishers, October 2013. p151.

23. K.V. Krishnan Vaidyan and S.Gopala Pillai. Sahasrayogam, Sujanapriya commentary, edition 32. Alappuzha; Vidyarambham publishers, October 2013. p152.

24. K.V. Krishnan Vaidyan and S.Gopala Pillai. Sahasrayogam, Sujanapriya commentary, edition
32. Alappuzha; Vidyarambham publishers, October 2013. p152.

25. K.V.Krishnan Vaidyan and S.Gopala Pillai. Sahasrayogam, Sujanapriya commentary, edition 32. Alappuzha; Vidyarambham publishers, October 2013. p153.

26. Kavitha KV and Sudheendra V Honwad, An experimental study on the antidote effect of maricha (Piper nigrum Linn) Kashaya in vatsanabha (Aconitum ferox) induced toxicity, The Pharma Innovation Journal. 2018; 7(7): 893-898.

27. K.V. Krishnan Vaidyan and S.Gopala Pillai. Sahasrayogam, Sujanapriya commentary, edition 32. Alappuzha; Vidyarambham publishers, October 2013. p.465.

28. Ravindra Angadi, Sri Sadanada Sarma, Rasa Tarangini, (English translation), Varanasi; Caukamba surbharati Prakashan; 2021. p.437.

29. Rohit K S et al. Review of Jwarahara Dravyas In Rasashastra. International Ayurvedic Medical Journal. 2015; 3(1); 112-116.

30. Ravindra Angadi, Sri Sadanada Sarma, Rasa Tarangini, (English translation), Varanasi; Caukamba surbharati prakashan; 2021. p.125

31. Rohit K S et al. Review of Jwarahara Dravyas In Rasashastra. International Ayurvedic Medical Journal. 2015; 3(1); 112-116.

32. Government of India. Ayurveda Pharmacopia of India, Part I, Volume II, Edition I, New Delhi; Ministry of Health and Family Welfare, Department of AYUSH; 1999. p.14.

33. Government of India. Ayurveda Pharmacopia of India. Ayurveda Pharmacopia of India, Part I, Volume IV, Edition I. New Delhi; Ministry of Health and Family Welfare, Department of AYUSH; 2004. p.92.

34. Government of India. Ayurveda Pharmacopia of India. Ayurveda Pharmacopia of India, Part I, Volume III, Edition I. New Delhi; Ministry of Health and Family Welfare, Department of AYUSH; 1999, p.11.

35. Dr Jaya Singh, Dr Praveen Raghuwanshi and Dr Prashant Tiwar Therapeutic Review of HerboMineral Preparation: Mrutprandayi Rasa. World Journal of Pharmaceutical and Medical Research. 2020; 6(11); 77-80.

36. Akhila Retnam. A Keerthi V., Reenu Mathew Sudheera. A Critical Review of Herbo-Mineral Formulations in Jwara Chikitsa, International Journal of Health Sciences and Research. 2021; 11(7); 394-406.

37. Akhila Retnam. A Keerthi V., Reenu Mathew Sudheera. A Critical Review of Herbo-Mineral Formulations in Jwara Chikitsa, International 
Journal of Health Sciences and Research. 2021; 11(7); 394-406.

38. Akhila Retnam. A Keerthi V., Reenu Mathew Sudheera. A Critical Review of Herbo-Mineral Formulations in Jwara Chikitsa, International Journal of Health Sciences and Research. 2021; 11(7); 394-406.

39. Malhotra D. Heavy metals in Ayurveda. 2006 Aug 26 [cited 2014 March 10]. In Boloji blog [Internet]. Available from: http://www.boloji.com/index.cfm ?md= Content $\&$ sd $=$ Articles\&ArticleID $=1098$

40. Seeneevassen Ajaghen, Nagras Madhuri Comparison of Kajjali Prepared By Traditional And Modern Methods, International Journal of Ayurveda and Pharma Research. 2014; 2(5); 50-56.

41. Dr Jaya Singh, Dr Praveen Raghuwanshi and Dr Prashant Tiwar Therapeutic Review of HerboMineral Preparation: Mrutprandayi Rasa. World Journal of Pharmaceutical and Medical Research. 2020, 6(11), 77-80.

42. Dr Jaya Singh, Dr Praveen Raghuwanshi and Dr Prashant Tiwar Therapeutic Review of HerboMineral Preparation: Mrutprandayi Rasa, wjpmr, 2020, 6(11), 77-80.

43. Dr Jaya Singh, Dr Praveen Raghuwanshi and Dr Prashant Tiwar Therapeutic Review of HerboMineral Preparation: Mrutprandayi Rasa, wjpmr, 2020, 6(11), 77-80.

44. Dr.Aishwarya Pandey, Chandrakant Upadhyay, Thakur Rakesh Singh, Saroj Parhate. Pharmaceutico-Analytical Study of Tribhuvanakirti Rasa. Journal of Ayurveda and Integrated Medical Sciences. 2021; 6(3); 27-34.
45. Rakesh Tiwle, D. K. Sanghi, Comprehensive Study of Nirgundi Plant: A Survey Report. Journal of Innovations in Pharmaceutical and Biological Sciences. 2015; Vol 2 (2); 125-130.

46. Saud Bawazeer, Abdur Rauf, and Sami Bawazeer Gastrointestinal Motility, Muscle Relaxation, Antipyretic and Acute Toxicity Screening of Amyrin Type Triterpenoid (Daturaolone) Isolated From Datura metel Linnaeus (Angel's Trumpet) Fruits. Frontiers in Pharmacology. 2020; 11: 544794.

47. [https://www.ncbi.nlm.nih.gov/pmc/articles/PMC 7546419/]

48. Jwan'an E., et.al., Evaluation of the AntiInflammatory, Anti-Nociceptive and Anti-Pyretic Effect of the Aqueous, Methanolic and N-Hexane Extract of Datura Metelseed on Albino Wister Rats. International Journal of Research and Innovation in Applied Science. 2021; VI (II); 57-63.

49. Swagata Tavhare et.al, Bhanga as an activity potentiator in Ayurvedic classics and Indian alchemy (Rasa sastra): A Critical Review. International Journal of Ayurvedic Medicine. 2016; 7(3), 136-152.

50. Ethnobotanical Survey of Medicinal Plants Used by Malayali Tribes in Yercaud Hills of Eastern Ghats, India, Journal of Natural Remedies. 2013; 13(2): 118-132.

51. Gunja K Dahikar, Bharat Rathi, Renu Rathi, Exploring the therapeutic potential of Gunja (Abrus precatorius Linn.): A classical semi-poisonous herbal drug, International Journal of Botany Studies. 2020; 5(6); 87-94.

\section{Cite this article as:}

KV Reshma Phalgunan, Madavi Subhashchandra. Review of Jwarahara Gutika Yogas Containing Vatsanabha in Sahasrayogam. International Journal of Ayurveda and Pharma Research. 2021;9(11):71-79.

https://doi.org/10.47070/ijapr.v9i11.2175

Source of support: Nil, Conflict of interest: None Declared

\section{*Address for correspondence Dr. KV Reshma Phalgunan}

PG Scholar,

Department of Rasasastra evum Bhaishajyakalpana, R.A. Podar Medical College (Ayu), Worli, Mumbai.

Mob: 9496472723

Email: reshmaphalgunan@gmail.com

Disclaimer: IJAPR is solely owned by Mahadev Publications - dedicated to publish quality research, while every effort has been taken to verify the accuracy of the content published in our Journal. IJAPR cannot accept any responsibility or liability for the articles content which are published. The views expressed in articles by our contributing authors are not necessarily those of IJAPR editor or editorial board members. 